\title{
CUSTOMER'S SATISFACTION ON ONLINE BANKING SERVICES OFFERED BY SELECTED PRIVATE AND PUBLIC SECTOR BANKS IN CHENNAI CITY
}

\author{
Dr. M. Raja
}

Assistant Professor and Head, Department of Commerce, Bharathidasan Unviersity Constituent College, Lalgudi, Tamil Nadu, India.

\section{Dr. M. Muthu Gopalakrishnan}

Associate Professor, School of Business Studies and Social Sciences, Christ (Deemed to be University), BGR Campus, Bengaluru, Karnataka, India.

\section{Dr. R. Venkatamuni Reddy}

Professor, Department of Commmerce Manipal Academy of Higher Education, Manipal, Karnataka, India

\section{Prof. A. Nagaraj Subbarao}

Dean- Center for Executive Education \& Professor- Scms, Dayananda sagar University, Innovation Campus, Hosur Main road, Bangalore, India

\begin{abstract}
The modern working life has to do job related work speedily and without maintaining, considering or balance in physical and psychological status. Modern world has theme to address various occupations along with the situation of stress. Employee's stress is a normal part of working life and workers have to face and cope with it. The aim of this research study is to identify the job-related stress and it's causing factors in public sector banks through an empirical study of employees. The result of job related stress is a deviation from the existing psychological and physical condition of employee's life. Based on this situation of employee's life is indicated as research problem of public sector banks. According to the findings of this research study, jobrelated stress factors of employees are correlated and influenced to their stress significantly. Employees stress is an important issue to be addressed to improve the performance of public sector banks in India. The study revealed that the public sector banks have accountability to reduce the level of stress of their employees.
\end{abstract}

Key word: Employees Stress, Workload, Well-being and Organizational Commitment. 
Cite this Article: Dr. M. Raja, Dr. M. Muthu Gopalakrishnan, Dr. R. Venkatamuni Reddy, Prof. A. Nagaraj Subbarao, Customer's Satisfaction on Online Banking Services Offered by Selected Private and Public Sector Banks in Chennai City, Journal of Management, 6 (2), 2019, pp. 310-319.

http://www.iaeme.com/JOM/issues.asp?JType=JOM\&VType=6\&IType=2

\section{INTRODUCTION}

In the year 2000 the Government of India introduced the Information Technology Act, 2000,(IT Act 2000). This act came in to effect from the 17th October 2000. The main aim of this act is to provide legal recognition to electronic transactions and Electronic Commerce. In continuation of this act RBI had set up a 'Working Group on Internet Banking' to examine different aspects of Internet banking (I-banking). The Group had examined the three major areas of I-banking i.e., technology and security issues, legal issues and regulatory and supervisory issues. RBI had accepted the recommendations of the Working Group on internet banking and accordingly issued guidelines on Internet banking in India for implementation by banks. Further the Working Group has also issued a report on Internet banking covering different aspects of Ibanking especially consolidating the existing payment systems and upgrading technology with a view to establishing an efficient, integrated and secure system functioning in a real-time environment.

\section{REVIEW OF LITERATURE}

Factors underlying attitude formation towards online banking in Finland reviewed by Heikki Karjaluoto Minna Mattila, Tapio Pento, (2002). This study determined the factors that are influence the formation attitude towards the internet banking. The result of the study provided the practical contributions in the area of electronic retail banking and understanding of consumer behaviour in the turbulent financial services industry of Finland.

Zhilin Yang \& Robin T. Peterson (2004) examined the Customer perceived value, satisfaction and loyalty with switching costs. The result of the study found that companies that strive for customer loyalty should focus primarily on satisfaction and perceived value. When the level of customer satisfaction is above the average the switching costs on association of customer loyalty and customer satisfaction are significant.

Consumers' attitudes towards online and mobile banking in China by Sylvie Laforet, Xiaoyan Li, (2005), investigated the market status for online/ mobile banking in China. The result of the study showed that Chinese online and mobile bank users were predominantly males, not necessarily young and highly educated, in contrast with the electronic bank users in the West. The main reasons for adopting the online banking by Chinese customers is issue of security.

Laforet, S \& Lo, X. (2005) analised the factors determining the mobile banking adoption among Access bank customers in Ghana. It is understand from the study that banks in Ghana should create more awareness through personal interaction with customers, develop quality initiatives in order to build customer's confidence. Equally, banks should also review the cost of their mobile banking service to attract new customers.

"Borneo online banking: evaluating customer perceptions and behavioral intention by Petrus Guriting, Nelson Oly Ndubisi, (2006), investigated the factors that are determining intension to use online banking in Malaysia Borneo. The study indicated that the perceived usefulness and ease of use are the important factors to adopt online banking in Malaysia. Computer self-efficacy and general computing experience are other important factors for adopt online banking. 
Malhotra, P. \& Singh, B. (2007) examined the factors affecting a bank's decision to adopt Internet banking in India. The researchers attempted to study the relationship between the bank's adoption decision and market characteristics. The results of the study indicate that larger banks, banks with younger age and banks which have large amounts of deposits have higher probability to adopt Internet banking.

Kamadkodi .N. \& Ahmed Khan, M.B. (2008), studied the customer expectations on EBanking service level in the present era. The results of the studied showed that technology alone cannot give sustainable competitive advantage rather than the service for the banks. Now banks are losing its identity and lose it position as a differentiator due to introduction of IT. In order t o retaining their existing clients and to attract new customers it is necessary to all banks to have personal touch with customers along with IT.

Cheolho Yoon (2010) investigated the customer satisfaction with online banking in China. The researcher investigated the effects of experience on the relationships between the antecedents and customer satisfaction. The results of the study showed that the variables like design, speed, security, information contents and customer support service have a significant influence on online banking customers.

Tooraj Sadeghi, Kambiz Heidarzadeh Hanzaee (2010) studied the Customer satisfaction factors (CSFs) with online banking services in an Islamic country: I.R. Iran using seven factors convenience, accessibility, accuracy, security, usefulness, bank image, and web site design. The researchers found that there is a significance difference between male and females underlying customer satisfaction with electronic banking services in the Islamic country, Iran.

Hazlina Abdul Kadir, Nasim Rahmani and Reza Masinaei (2011) portrait the effect of services offered by Malaysian banks through online media. This is attempted to identify among the ATM, Customer satisfaction, Online banking, Service quality, which factors have the most effect and which factors have the least effect on customer satisfaction level. Finally the researcher concluded that Malaysian anchor banks are required to improve their services in order to fulfill the customers need

A study by Chu, Po-Young; Lee, Gin-Yuan; Chao, Yu (2012) entitled Service Quality, Customer Satisfaction, Customer Trust, and Loyalty in an E-Banking Context examined the relationships between service quality, customer satisfaction in, customer trust of, and loyalty to Taiwanese e-banks. The result of the study found that that e-bank must focus on service quality to increase customer satisfaction and trust and to obtain customer loyalty. Implications are discussed in relation to e-bank management.

\section{STATEMENT OF PROBLEM}

The financial reforms that were initiated in the early 90s and the globalization and liberalization measures brought in a completely new operating environment to the banks. Indian banking industry, today, is in the peak of an IT revolution. The technology changes have increased the competition and automation in the Indian banking industry. Private sector banks and foreign banks have an edge over public sector banks for implementation of technological solutions. Now the concept of Anywhere Banking, Tele-Banking, Internet Banking, Web Banking and EBanking are very popular in Indian banking industry to cope with the competition by offering innovative and attractive technology based services to their customers. Private and foreign banks have adopted the e-banking (online banking) earlier whereas the public sector banks are beginning to hold on to the competition. With this background the present study is attempted to study the customer's satisfaction towards online banking services offered by selected private and public sector banks at Chennai city. 


\section{OBJECTIVES OF THE STUDY}

To study the customer satisfaction towards the online banking services of both private and public sector banks the following objectives are framed.

- To identify the factors those are influencing the customer's satisfaction in online banking of public \& private sector banks.

- To study the level of satisfactions of the customers using online banking of public \& private sector banks.

\subsection{Hypothesis of the Study}

The following are important hypothesis of the present study.

- Customers using the online banking service of public \& private sector banks are satisfied with banks prompt responses.

- Customers using the online banking of public \& private sector banks are satisfied with online banking security.

- Customers using the online banking of public \& private sector banks are satisfied with Reliability \& confidence.

- Customers using the online banking of public \& private sector banks are satisfied with Efficiency of Website.

- Customers using the online banking of public \& private sector banks are satisfied with Competence.

- Customers using the online banking of public \& private sector banks are satisfied with Website Design \&Ease of use.

\section{RESEARCH METHODOLOGY}

The purpose of this study is help to fill significant gaps in customer satisfaction towards online banking services landscape in India. The period chosen for the present study is 2018. For the purpose of analysis data were collected from 150 persons from both public \& private sector banks customers who are using the online banking services. These customers were chosen from only three public sector banks (SBI, Canara Bank, Indian Bank) and three private sectors (HDFC bank, ICICI bank and Axis bank) at Chennai. The data for this study are unique in several respects. First, the data covers the selected private and public sector banks which are offering the online banking services. Secondly, the information was compiled from the websites of the respective banks.

\subsection{Limitations of the Study}

- The sample taken for the purpose of study comprises only three private \& public sector banks at Chennai city.

- Only important products and services of online banking are studied. The online banking products and services used for this study are not concluding.

- The information about the various services and products of online banking being offered by the public \& private sector banks at Chennai has been explored from the web sites of concern banks only. No other information source has been availed.

\section{ANALYSIS AND DISCUSSIONS:}

To study the customers' satisfaction towards online banking services offered by both private and public banks at Chennai two important tests were employed. First one is KMO \& Bartlett's test to check whether the data is appropriate to proceed with the factor analysis or not. Second one is factor analysis to study six-dimension customer satisfaction variables. 
Dr. M. Raja, Dr. M. Muthu Gopalakrishnan, Dr. R. Venkatamuni Reddy, Prof. A. Nagaraj Subbarao

Table 1 KMO \& Bartlett's Test

\begin{tabular}{|c|c|c|}
\hline \multicolumn{3}{|c|}{ KMO \& Bartlett's Test } \\
\hline \multicolumn{2}{|c|}{ KMO Measures of Sampling Adequacy } & 0.716 \\
\hline \multirow{2}{*}{ Bartlett's Test of Sphericity } & Approx. Chi-Square & 1472.59 \\
\cline { 2 - 3 } & Degree of Freedom & 241 \\
\cline { 2 - 3 } & Significance & 0 \\
\hline
\end{tabular}

The six-dimension customer satisfaction variables had Coefficient alpha of 0.716. It is a good score of satisfactory, compared to standard 0.70 score (Sekaran, 2005). KMO and Bartlett's test of Sphericity was significant (Chi-Square - 1472.59, p<0.000). The KMO measure of sampling adequacy was higher at 0.691and the value exceeded the recommended value of 0.60 (Kaiser, 1974). The results of KMO and Bartlett's test suggest that the data is appropriate to proceed with the factor analysis.

\subsection{Customer Satisfaction towards internet banking services of Public Sector Banks- Factor Analysis}

The present study attempted to analyse the customer satisfaction on online banking services using Principal Component Analysis method. In the present study there are six variables considered called banks prompts responses, online banking securities, reliability and confidence, efficiency of website, competence and website design \& Ease of use both private and public sector banks.

Table 2 Customer satisfactions towards Banks prompts responses of Public \& Private sector Banks

\begin{tabular}{|c|c|c|c|c|c|c|c|c|c|}
\hline \multirow{2}{*}{ S.No } & \multirow{2}{*}{$\begin{array}{l}\text { Factors consider } \\
\text { under banks } \\
\text { prompts responses }\end{array}$} & \multicolumn{2}{|c|}{ Factor loading } & \multicolumn{2}{|c|}{ Eigen Values } & \multicolumn{2}{|c|}{$\begin{array}{c}\text { Percentage of } \\
\text { Variance }\end{array}$} & \multicolumn{2}{|c|}{ Reliability } \\
\hline & & Public & Private & Public & Private & Public & Private & Public & Private \\
\hline $\mathrm{a}$ & $\begin{array}{l}\text { Online banking } \\
\text { transaction always } \\
\text { speed \& accurate }\end{array}$ & 0.872 & 0.762 & \multirow{7}{*}{$\begin{array}{c}\text { (Cronbach } \\
\alpha= \\
11.574)\end{array}$} & \multirow{7}{*}{$\begin{array}{c}\text { (Cronbach } \\
\alpha= \\
11.574)\end{array}$} & \multirow{7}{*}{27.614} & \multirow{7}{*}{25.714} & \multirow{7}{*}{$(0.764)$} & \multirow{7}{*}{$(0.764)$} \\
\hline $\mathrm{b}$ & $\begin{array}{l}\text { Confirmation of } \\
\text { transactions done at } \\
\text { Website }\end{array}$ & 0.851 & 0.742 & & & & & & \\
\hline $\mathrm{c}$ & $\begin{array}{l}\text { Staff gives personal } \\
\text { attention for } \\
\text { customers' queries. }\end{array}$ & 0.812 & 0.723 & & & & & & \\
\hline d & $\begin{array}{l}\text { Services delivered } \\
\text { at exact time as } \\
\text { mentioned in } \\
\text { website }\end{array}$ & 0.807 & 0.729 & & & & & & \\
\hline $\mathrm{e}$ & $\begin{array}{l}\text { Maintenance of } \\
\text { error free records } \\
\text { by bank }\end{array}$ & 0.759 & 0.648 & & & & & & \\
\hline $\mathrm{f}$ & $\begin{array}{l}\text { Sincerity in solving } \\
\text { customers' problem }\end{array}$ & 0.714 & 0.637 & & & & & & \\
\hline g & $\begin{array}{l}\text { Confirmation of } \\
\text { transactions done at } \\
\text { Website }\end{array}$ & 0.872 & 0.762 & & & & & & \\
\hline
\end{tabular}

Table -2 explains the customer satisfaction towards banks prompts responses. Principal Component Analysis revealed six factors with Eigen value exceeding 1.0 explaining the variance up to 27.614 for public sector banks and 25.714 for private sector banks. The variance up to 0.872 in public sector banks and 0.762 in private sector banks for Online banking transaction always speed \& accurate, 0.851 in public sector banks and 0.742 in private sector banks for confirmation of transactions done at Website, 0.812 in public sector banks and 0.723 for private sector banks for staff gives personal attention for customers' queries, 0.807 in public sector banks and 0.729 in private sector banks for services delivered at exact time as mentioned 
in website, 0.759 in public sector banks and 0.648 in private sector banks for maintenance of error free records by bank, 0.714 in public sector banks and 0.637 in private sector banks for sincerity in solving customers' problem and 0.872 in public sector banks and 0.762 in private sector banks for confirmation of transactions done at website. To determine the important factors of customer satisfaction towards bank prompts responses varimax rotation performed for 6 factors. These factors were labeled according the variables. The factor analysis reveals that reliability measures exceeded the minimum value of 0.60 for all variables for both public and private sector banks. Hence the hypothesis -1 Customer using the online banking service of public \& private sector banks are satisfied with banks prompt responses is accepted.

Table 3 Customer satisfactions towards online banking security of Public \& Private Sector Banks

\begin{tabular}{|c|c|c|c|c|c|c|c|c|c|}
\hline \multirow[t]{2}{*}{ S.No } & \multirow{2}{*}{$\begin{array}{c}\text { Factors consider } \\
\text { under internet } \\
\text { banking security }\end{array}$} & \multicolumn{2}{|c|}{ Factor loading } & \multicolumn{2}{|c|}{ Eigen Values } & \multicolumn{2}{|c|}{$\begin{array}{c}\text { Percentage of } \\
\text { Variance }\end{array}$} & \multicolumn{2}{|c|}{ Reliability } \\
\hline & & Public & Private & Public & Private & Public & Private & Public & Private \\
\hline $\mathrm{a}$ & $\begin{array}{l}\text { Security features in } \\
\text { Website }\end{array}$ & 0.859 & 0.748 & \multirow{4}{*}{$\begin{array}{l}\text { (Cronbach } \\
\alpha=3.578)\end{array}$} & \multirow{4}{*}{$\begin{array}{c}\text { (Cronbach } \\
\alpha=3.785)\end{array}$} & \multirow{4}{*}{10.849} & \multirow{4}{*}{9.742} & \multirow{4}{*}{$(0.814)$} & \multirow{4}{*}{$(0.894)$} \\
\hline $\mathrm{b}$ & $\begin{array}{l}\text { Bank staff support \& } \\
\text { infuse customer } \\
\text { confidence }\end{array}$ & 0.837 & 0.716 & & & & & & \\
\hline $\mathrm{c}$ & $\begin{array}{l}\text { Delivery of } \\
\text { confidential } \\
\text { information's to } \\
\text { customers }\end{array}$ & 0.715 & 0.605 & & & & & & \\
\hline d & $\begin{array}{l}\text { Influence of up-to- } \\
\text { date web info }\end{array}$ & 0.621 & 0.513 & & & & & & \\
\hline
\end{tabular}

Table -3 depicts the customer satisfaction towards online banking security. Principal Component Analysis revealed four factors with Eigen value exceeding 1.0 explaining the variance up to 10.849 for public sector banks and 9.742 for private sector banks. The variance up to 0.859 in public sector banks and 0.748 in private sector banks for Security features in Website, 0.837 in public sector banks and 0.716 in private sector banks for Bank staff support $\&$ infuse customer confidence, 0.715 in public sector banks and 0.605 in private sector banks for Delivery of confidential information's to customers and 0.621 in public sector banks and 0.513 for private sector banks for influence of up-to-date web info. To determine the important factors of customer satisfaction towards online banking security varimax rotation performed for four factors. These factors were labeled according the variables. The factor analysis reveals that reliability measures exceeded the minimum value of 0.60 for all variables. Hence the hypothesis-2 Customers using the online banking of public \& private sector banks are satisfied with online banking security are accepted.

Table 4 Customer Satisfactions towards Reliability \& Confidence of Public \& Private Sector Banks

\begin{tabular}{|c|c|c|c|c|c|c|c|c|c|}
\hline \multirow{2}{*}{ S.No } & \multirow{2}{*}{$\begin{array}{l}\text { Factors consider } \\
\text { under Reliability \& } \\
\text { confidence }\end{array}$} & \multicolumn{2}{|c|}{ Factor loading } & \multicolumn{2}{|c|}{ Eigen Values } & \multicolumn{2}{|c|}{$\begin{array}{l}\text { Percentage of } \\
\text { Variance }\end{array}$} & \multicolumn{2}{|c|}{ Reliability } \\
\hline & & Public & Private & Public & Private & Public & Private & Public & Private \\
\hline $\mathrm{a}$ & $\begin{array}{l}\text { Staff keeps the } \\
\text { promises }\end{array}$ & 0.853 & 0.742 & \multirow{3}{*}{$\begin{array}{l}\text { (Cronbach } \\
\alpha=2.437)\end{array}$} & \multirow{3}{*}{$\begin{array}{l}\text { (Cronbach } \\
\alpha=2.758 \text { ) }\end{array}$} & \multirow[b]{3}{*}{5.452} & \multirow[b]{3}{*}{5.876} & \multirow[b]{3}{*}{$(0.712)$} & \multirow[b]{3}{*}{$(0.792)$} \\
\hline $\mathrm{b}$ & $\begin{array}{l}\text { Third parties can't } \\
\text { access of financial } \\
\text { information }\end{array}$ & 0.751 & 0.640 & & & & & & \\
\hline $\mathrm{c}$ & $\begin{array}{l}\text { Understands the } \\
\text { specific needs of } \\
\text { customers }\end{array}$ & 0.647 & 0.538 & & & & & & \\
\hline
\end{tabular}

Table -4 shows the customer satisfaction towards reliability and confidence. Principal Component Analysis revealed three factors with Eigen value exceeding 1.0 explaining the variance up to 5.452 for public sector banks and 5.876 for private sector banks. The variance 
up to 0.853 for public sector banks and 0.72 for private sector banks in Staff keeps the promises, 0.751 for public sector banks and 0.640 for private sector banks in third parties can't access of financial information and 0.647 for public sector banks and 0.538 for private sector banks in understands the specific needs of customers. To determine the important factors of customer satisfaction towards Reliability \& confidence varimax rotation performed for three factors. These factors were labeled according the variables. The factor analysis reveals that reliability measures exceeded the minimum value of 0.60 for all variables. Hence the hypothesis -3 customers using the online banking of public \& private sector banks are satisfied with reliability $\&$ confidence are accepted.

Table 5 Customer Satisfaction towards Efficiency of Website of Public \& Private Sector Banks

\begin{tabular}{|l|l|l|l|l|l|l|l|l|l|}
\hline \multirow{2}{*}{ S.No } & \multirow{2}{*}{$\begin{array}{l}\text { Factors consider } \\
\text { under Efficiency of } \\
\text { Website }\end{array}$} & \multicolumn{2}{|l|}{ Factor loading } & \multicolumn{2}{l|}{ Eigen Values } & \multicolumn{2}{l|}{$\begin{array}{l}\text { Percentage of } \\
\text { Variance }\end{array}$} & \multicolumn{2}{l|}{ Reliability } \\
\cline { 3 - 10 } & Public & Private & Public & Private & Public & Private & Public & Private \\
\hline a & $\begin{array}{l}\text { website performs the } \\
\text { service in the first } \\
\text { instance itself }\end{array}$ & 0.847 & 0.759 & $\begin{array}{l}\text { (Cronbach } \\
\alpha=1.746)\end{array}$ & $\begin{array}{l}\text { (Cronbach } \\
\alpha=1.857)\end{array}$ & 5.892 & 5.986 & $(0.756)$ & $(0.798)$ \\
\hline b & $\begin{array}{l}\text { I trust bank keeps } \\
\text { confidential info }\end{array}$ & 0.732 & 0.643 & & & & & & \\
\end{tabular}

Table -5 reflects the customer satisfaction towards efficiency of website. Principal Component Analysis revealed two factors with Eigen value exceeding 1.0 explaining the variance up to 5.892 for public sector banks and 5.986 for private sector banks. The variance up to 0.847 for public sector banks and 0.759 for private sector banks in website performs the service in the first instance itself and 0.732 for public sector banks and 0.643 for private sector banks in I trust bank keeps confidential info. To determine the important factors of customer satisfaction towards efficiency of website varimax rotation performed for two factors. These factors were labeled according the variables. The factor analysis reveals that reliability measures exceeded the minimum value of 0.60 for all variables. Hence the hypotheses -4 Customers using the online banking of public \& private sector banks are satisfied with Efficiency of Website are accepted.

Table 6 Customer satisfaction towards Competence of Public \& Private Sector Banks

\begin{tabular}{|c|c|c|c|c|c|c|c|c|c|}
\hline \multirow[t]{2}{*}{ S.No } & \multirow{2}{*}{$\begin{array}{l}\text { Factors consider } \\
\text { under Competence }\end{array}$} & \multicolumn{2}{|c|}{ Factor loading } & \multicolumn{2}{|c|}{ Eigen Values } & \multicolumn{2}{|c|}{$\begin{array}{l}\text { Percentage of } \\
\text { Variance }\end{array}$} & \multicolumn{2}{|c|}{ Reliability } \\
\hline & & Public & Private & Public & Private & Public & Private & Public & Private \\
\hline $\mathrm{a}$ & $\begin{array}{l}\text { staff is friendly and } \\
\text { courteous }\end{array}$ & 0.843 & 0.758 & \multirow[b]{2}{*}{$\begin{array}{l}\text { (Cronbach } \\
\alpha=1.962)\end{array}$} & \multirow[b]{2}{*}{$\begin{array}{l}\text { (Cronbach } \\
\alpha=1.874)\end{array}$} & \multirow[b]{2}{*}{4.172} & \multirow[b]{2}{*}{4.586} & \multirow[b]{2}{*}{$(0.716)$} & \multirow[b]{2}{*}{$(0.798)$} \\
\hline $\mathrm{b}$ & $\begin{array}{l}\text { satisfied with service } \\
\text { of I-banking }\end{array}$ & 0.748 & 0.684 & & & & & & \\
\hline
\end{tabular}

Table -6 tells about the customer satisfaction towards competence. Principal Component Analysis revealed two factors with Eigen value exceeding 1.0 explaining the variance up to 4.172 for public sector banks and 4.586 for private sector banks. The variance up to 0.843 for public sector banks and 0.758 for private sector banks in staff is friendly and courteous and 0.748 for public sector banks and 0.684 for private sector banks in satisfied with service of online banking. To determine the important factors of customer satisfaction towards competence varimax rotation performed for two factors. These factors were labeled according the variables. The factor analysis reveals that reliability measures exceeded the minimum value of 0.60 for all variables. Hence the hypotheses -5 Customers using the online banking of public $\&$ private sector banks are satisfied with Competence are accepted. 
Customer's Satisfaction on Online Banking Services Offered by Selected Private and Public Sector Banks in Chennai City

Table 7 Customer satisfaction towards Website Design \&Ease of use of Public \& Private Sector Banks

\begin{tabular}{|c|c|c|c|c|c|c|c|c|c|}
\hline \multirow{2}{*}{ S.No } & \multirow{2}{*}{$\begin{array}{l}\text { Factors consider under } \\
\text { Website Design \&Ease } \\
\text { of use }\end{array}$} & \multicolumn{2}{|c|}{ Factor loading } & \multicolumn{2}{|c|}{ Eigen Values } & \multicolumn{2}{|c|}{$\begin{array}{l}\text { Percentage of } \\
\text { Variance }\end{array}$} & \multicolumn{2}{|c|}{ Reliability } \\
\hline & & Public & Private & Public & Private & Public & Private & Public & Private \\
\hline $\mathrm{a}$ & $\begin{array}{l}\text { Simple \& } \\
\text { understandable } \\
\text { guidance screen }\end{array}$ & 0.732 & 0.645 & \multirow{4}{*}{$\begin{array}{l}\text { (Cronbach } \\
\alpha=2.572 \text { ) }\end{array}$} & \multirow{4}{*}{$\begin{array}{l}\text { (Cronbach } \\
\alpha=2.894)\end{array}$} & \multirow{4}{*}{5.261} & \multirow{4}{*}{5.874} & \multirow{4}{*}{$(0.736)$} & \multirow{4}{*}{$(0.796)$} \\
\hline $\mathrm{b}$ & $\begin{array}{l}\text { Staff performs service } \\
\text { right the first time }\end{array}$ & 0.756 & 0.684 & & & & & & \\
\hline $\mathrm{c}$ & $\begin{array}{l}\text { Quick service } \\
\text { delivered via website }\end{array}$ & 0.649 & 0.578 & & & & & & \\
\hline $\mathrm{d}$ & $\begin{array}{l}\text { Satisfied with the } \\
\text { security system }\end{array}$ & 0.617 & 0.586 & & & & & & \\
\hline
\end{tabular}

Table -7 explains customer satisfaction towards website design \&Ease of use. Principal Component Analysis revealed four factors with Eigen value exceeding 1.0 explaining the variance up to 5.261 for public sector banks and 5.874 for private sector banks. The variance up to 0.732 for public sector banks and 0.645 for private sector banks in simple \& understandable guidance screen, 0.756 for public sector banks and 0.684 for private sector banks in staff performs service right the first time, 0.649 for public sector banks and 0.578 for private sector banks in quick service delivered via website and 0.617 for public sector banks and 0.586 for private sector banks in satisfied with the security system. To determine the important factors of customer satisfaction towards Website Design \&Ease of use varimax rotation performed for four factors. These factors were labeled according the variables. The factor analysis reveals that reliability measures exceeded the minimum value of 0.60 for all variables. Hence the hypothesis-6 Customers using the online banking of public \& private sector banks are satisfied with Website Design \&Ease of use are accepted.

\section{FINDINGS, SUGGESTIONS AND CONCLUSIONS:}

\subsection{Findings from the Study}

The following are important findings of the present study

- This is understand from the present study that bank prompt responses for customer quires are influence the satisfaction of the customers who are using the online banking services of public $\&$ private sector banks.

- This is found from the present study that security features of public \& private sector banks are influences the satisfaction of the customers who are using the online banking services of public sector banks.

- Website design \& ease of use of public \& private sector banks are highly influence the satisfaction of the online bank customers of public sector banks.

- The present study depicts the fact that reliability and confidence of public \& private sector banks are significantly influence the satisfactions of the customers who are using the online banking services of public sector banks.

- It is obvious from the present study that competence and efficiency of the website are highly influence the satisfaction of the customers who are using the online banking services of public $\&$ private sector banks.

- $\quad$ The sample public \& private sector banks are using the Email, SMS and Phone for responding the customer quires and used these tools for communicating with customers.

- Public \& private sector banks are giving higher priority to safeguard the customer's information with help of latest electronic packages. 
- Majority of the customers using the online banking services of public \& private sector banks are satisfied with banks website design and its easy usage.

- Public \& private sector banks are providing reliable online banking services through that they are getting the customer's confidence.

- Finally, almost all the public \& private sector banks websites are more efficient in providing the online banking services.

\subsection{Suggestions from the study}

The following are important suggestions from the present study

- The Public \& private sector banks should provide regular communications to customers regarding security feature.

- The public \& private sector banks should provide SMS immediate as soon as the transactions are over regarding the details of the latest transactions to prevent the misuse of customer's privacy information.

- Public \& private sector banks web portals should focus the information and navigation steps for smooth transaction of customers

- When customers using the public \& private sector bank websites the bank should understand the better of customers and customize the products and services.

- The public \& private sector banks should customize their product and services to cover all categories of people.

- The public \& private sector bankers should adopt the latest technology to increasing the virtual banking

- Public \& private sector banks has to focus on providing suitable content and navigation features not only on banking and should include other financial services as better service to the customers.

\section{CONCLUSIONS}

The present study on customer satisfaction towards online banking services covers only three public sector banks and three private sector banks at Chennai. The results of the present study shows that both private and public sector banks websites and technology platforms has to offer various knowledge features on financial services with collaboration of other financial institutions. The usage of up to date information and technologies for customer communication enhance the customer satisfaction. The study is limited to exploring customer satisfaction on internet banking services provided by sample private and public sector banks. To retain the existing customers, both private and public sector banks has to conduct regular surveys on the customer satisfaction, study the trends of banking periodically and communicate the information for customer usage and know the change of customer profiles for effective customer satisfaction. Future studies can focus on mobile banking, telephone banking, and support services provided by banks for exploration.

\section{REFERENCES}

[1] Heikki Karjaluoto, Minna Mattila, Tapio Pento, "Factors underlying attitude formation towards online banking in Finland", International Journal of Bank Marketing, Vol. 20 Issue: 6, 2002, P.p.261-272.

[2] Zhilin Yang \& Robin T. Peterson, "Customer perceived value, satisfaction, and loyalty: The role of switching costs,” Psychology \& Marketing, Volume-21, Issue-10, October -2004, P.p 799-822.

[3] Sylvie Laforet, Xiaoyan Li, “Consumers' attitudes towards online and mobile banking in China", International Journal of Bank Marketing, Vol. 23 Issue: 5, 2005, P.p.362-380. 
[4] Laforet, S \& Lo, X, Consumers' attitudes towards online and mobile banking in China, International Journal of Bank Marketing, 23(5), 2005, pp.362-380.

[5] Petrus Guriting, Nelson Oly Ndubisi, "Borneo online banking: evaluating customer perceptions and behavioral intention", Management Research News, Vol-29 Issue-1/2, 2006, Pp.6-15.

[6] Malhotra, P. \& Singh, B, Determinants of Internet banking adoption by banks in India, Internet Research, 17(3), 2007, pp.323-333.

[7] Kamadkodi .N. \& Ahmed Khan, M.B, Customer expectations and service level in E-banking Era: An empirical study, The ICFAI University Journal of Bank Management, 7(4), 2008, pp.50-70.

[8] CheolhoYoon, "Antecedents of customer satisfaction with online banking in China: The effects of experience", Computers in Human Behavior, Volume - 26, Issue - 6, November- 2010, 2010, P.p 1296-1304.

[9] Tooraj Sadeghi, Kambiz Heidarzadeh Hanzaee,"Customer satisfaction factors (CSFs) with online banking services in an Islamic country: I.R. Iran", Journal of Islamic Marketing, Vol. 1 Issue: 3, 2010, P.p.249-267.

[10] Hazlina Abdul Kadir, Nasim Rahmani and Reza Masinaei, "Impacts of service quality on customer satisfaction: Study of Online banking and ATM services in Malaysia" International Journal of Trade, Economics and Finance, Vol.2, No.1, February, 2011.

[11] Chu, Po-Young; Lee, Gin-Yuan; Chao, Yu, "Service Quality, Customer Satisfaction, Customer Trust, and Loyalty in an E-Banking Context", Social Behavior and Personality: an international journal, Volume 40, Number 8, 2012, P.p. 1271-1283(13). 